\title{
The Causal Impact of Media in Financial Markets*
}

\author{
J oseph Engelberg \\ Christopher A. Parsonsł
}

October 2009

\begin{abstract}
It is challenging to disentangle the causal impact of media reporting from the impact of the events being reported. We solve this problem by comparing the behaviors of investors with access to different media coverage of the same information event. We use zip codes to identify 19 mutually exclusive trading regions, corresponding to 19 large U.S. cities and local newspapers (e.g., the Houston Chronicle). For all earnings announcements of S\&P 500 Index firms, we find that local media coverage strongly predicts local trading, after controlling for characteristics of the earnings surprise, firm, local investors, and reporting newspaper(s). Moreover, the local trading-local coverage effect: 1) depends precisely on the specific timing of local reporting (e.g., one day after the earnings announcement, two days afterward, etc.) and 2) disappears entirely during extreme weather events, which leaves media content unchanged, but disrupts transmission to investors.
\end{abstract}

* We thank Nick Barberis, Mike Fishman, Matthew Gentzkow, Jay Hartzell, David Hirshleifer, David Matsa, Mitchell Petersen, Robert McDonald, J esse Shapiro, Paul Tetlock, Sheridan Titman, Luigi Zingales and seminar participants at Northwestern University for helpful feedback and discussions. We thank Terry Odean for providing the large discount brokerage data.

¥ Contact: J oseph Engelberg, Kenan-Flagler Business School, University of North Carolina at Chapel Hill, (Email) joseph engelberg@kenan-flagler.unc.edu, (Tel) 919-962-6889 and Christopher Parsons, KenanFlagler Business School, University of North Carolina at Chapel Hill, (Email) chris parsons@kenanflagler.unc.edu, (Tel) 919-962-4132. Please address all correspondence to J oseph Engelberg. 


\section{Introduction}

A number of recent studies have demonstrated strong correlations between stories reported by the media and stock market reactions. ${ }^{1}$ This paper addresses whether a causal relation between the two exists. Specifically, we ask whether media coverage of a financial event can change how investors respond.

Showing a causal relation is challenging because media coverage is not random, instead the product of profit maximization by newspapers, television, magazines, etc. (Gentzkow and Shapiro, 2008). Because a number of unobservable factors that influence these coverage decisions also affect investor behavior, an identification problem arises. Given an event of interest, how can we tell whether the media's coverage altered the market's response, or whether some unobserved feature of the event simultaneously drove both coverage and market reaction?

Researchers have taken two approaches to solve this problem. The first is to carefully select events in which determinants of media coverage and market responses can be decoupled. For example, Huberman and Regev (2001) detail the now famous Entremed anecdote, in which a feature story in the New York Times catalyzed an immediate fourfold increase in Entremed's stock price. The curious aspect was that virtually all the "information" reported in the NYT story was already public (which the authors show in detail), making it unlikely that failure to control for the salience of such events could explain the subsequent market reaction. While convincing in this case, the general drawback to such an approach goes beyond the impracticality of requiring clinical dissection for each candidate event. How can one ever be certain to have controlled for all other simultaneous determinants of investor demand and media coverage, particularly when they are unobservable (e.g., "soft signals")?

The second, a cross-sectional approach, sidesteps this criticism. The basic idea is to take two groups of agents, and for the same information event, vary only media exposure. DellaVigna and Kaplan (2007) employ this strategy, showing that voting patterns could be

\footnotetext{
${ }^{1}$ See, for example, Tetlock (2007), Tetlock at el. (2008), and Peress (2008).
} 
predicted by whether an area's local cable provider picked up Fox News. Likewise, Gerber et al. (2009) randomly assign households in the Washington D.C. area to receive a subscription of either the Times or the Post, finding that political views were altered. Of course, in each study the coverage decisions of the individual media outlets remain endogenous, but delivery is not.

Our study takes the second approach and is, to our knowledge, the first to do so within the study of financial markets. Using retail brokerage accounts, we first identify nineteen local, non-overlapping trading markets coinciding with major U.S. cities. Then, for each of these markets, we identify a local information source: the daily newspaper of that city. Especially during our pre-internet time period, investors near Minneapolis (for instance) were more likely to read the Minneapolis Star Tribune than local papers in other regions, such as the Seattle Post Intelligencer. This linkage and the fact that local media outlets often differ in their coverage of the same underlying event affords a powerful test of the media's effects on financial market participants.

The main result is that for an earnings announcement by a given S\&P 500 Index firm, trading in each of the nineteen local markets is strongly related to whether the local paper covers the announcement. All else equal, local press coverage increases the trading volume of local retail investors by nearly 50\%. Although somewhat stronger for buying activity, the local media-local trading effect remains significant for selling as well.

We interpret these results causally, with media coverage stimulating local trading activity. The main alternative is that even though the underlying event is fixed, a local paper's coverage decisions may be related to unobserved local determinants of local trading. For example, we might imagine that geographic proximity matters: the Star Tribune might be more likely to report on Minnesota-based ADC Telecom because local investors are interested in it. More generally, any factor that makes a given company's earnings more interesting to local readers is presumably a more attractive story subject for a local media outlet. Perhaps a merger 
between ADC Telecom and a firm based in Denver will render the latter's earnings more relevant for Minnesota investors.

We address this possibility three ways. First, we include a number of controls intended to control for determinants of local coverage and local trading. For instance, we collect data on the local stock portfolio positions of Minnesota investors, using recent transactions and holdings to measure existing interest. The local coverage-local trading remains strong despite these controls. For robustness, we also estimate our regressions including fixed effects for every (1) firm-city, (2) firm-earnings date, and (3) city-earnings date pairing. The first of these, for example, controls for the proximity between each newspaper (or city) and firm in our sample, capturing any home bias on the part of investors (e.g., Coval and Moskowitz (1999, 2001), Ivkovic and Weisbenner (2005)) or local media (Butler and Gurun (2008)). The second set of fixed effects is equally important. Other information is often released around earnings, including guidance from the firm itself, management interviews, recommendations of analysts, etc. Because these may change over time for a given firm, we include a dummy variable for, say, ADC Telecom's earnings announcement in the third quarter of 1993. The final set of effects models any remaining city-level heterogeneity that may influence trading at a given time, such as time-varying local economic conditions or fluctuations in a city's investor participation. Even when all three are included simultaneously, local media coverage remains a strong predictor of local trading.

Our most precise tests identify media effects from the correlation between local trading and exogenous variation in local media coverage, fluctuation that cannot plausibly be related to other determinants of trading activity. We develop two approaches. The first exploits the fact that our sample period (1991-1996) mostly predates the Internet, so that investors depended on physical delivery of their print media sources. We collect data on the daily weather in each local market, and identify weather events severe enough to likely disrupt or delay delivery of the local newspapers: blizzards and hailstorms. Although a blizzard in Minneapolis may make it less 
likely that the Star Tribune will reach its readers, it is clearly unrelated to the Star Tribune's financial reporting -- perhaps a story on the earnings of Starbucks some 1500 miles away -- or preferences of Minneapolis investors. On such days, we find that the relation between local trading and local media coverage is severed. Crucially, this is not simply an extreme weather effect; extreme weather is unrelated to local retail trading. It is the interaction with media coverage (which is similar on extreme weather days) that predicts investor behavior.

Our final test exploits micro-level variation in the timing of publication. Overwhelmingly, if an earnings story is going to be published locally, it will be within three days of the announcement. About $40 \%$ of such stories break on the first day (call this day one), another $50 \%$ on day two, and the balance on day three. One possible explanation is that newspapers have different print deadlines, potentially exacerbated by differences in time zones. For example, one can imagine the earnings of Dell Computer released late Wednesday afternoon meeting the Seattle Post-Intelligencer's print deadline for Thursday's morning edition, but missing it for the Minneapolis Star Tribune (ahead by two time zones), which carries the story on Friday. Differences in printing technology may also alter how quickly newspaper can translate information into a printed story.

Regardless of the specific mechanism, we posit that whether story breaks locally on day one, two, or three is almost certainly uncorrelated with unobservable determinants of local investor demand. The specific question we ask is, after controlling for all the fixed effects (e.g., firm-city, firm-date), is local trading best predicted on the exact day that local coverage occurs? It is. In regressions of local trading on day one (the first possible day coverage can occur), only local coverage on day one predicts trading. Coverage initiated on (future) days two or three have no effect on trading; note that this is a test for falsification, whose results suggest that the model is well-specified. Identical evidence is found for the "day two" and "day three" trading regressions. For these as well, only local media coverage on the specific day of interest predicts local trading on that day. 
By identifying the causal effect of media on trading volume, our study contributes to two distinct literatures. The first explores the media's influence on real outcomes (e.g., Stromberg (2004), Gentzkow and Shapiro (2004), Gentzkow (2006), and Gerber et al. (2009)). Our results constitute the first systematic identification of the media's effects on investor behavior, and lay the groundwork for future work that explores in more detail the specific mechanisms underlying its influence. The second literature examines the unusually high trading volume in financial markets. A popular justification for the "volume puzzle" is that investors have differences of opinion (e.g., Hong and Stein (2007)), and are thus willing to bear the adverse selection cost of potentially trading with agents differentially informed. ${ }^{2}$ However, such opinion differences are usually taken as exogenous, begging the question exactly what mechanism is responsible for their generation. Our results provide a simple answer: differential media coverage may lead to agents with heterogeneous information. Moreover, the growth in trading volume may be related to the exponential growth of media sources, which can generate substantial investor heterogeneity.

The remainder of the paper is onganized as follows. In section II we describe in more detail the nature of the identification problem we wish to solve, and in Section III briefly describe the data and its sources. Next, we examine trading of retail investors in a number of local markets, with a particular eye on local media coverage in Section IV. We then consider how the endogeneity of local media coverage affects our conclusions and designs several related tests in Section V. The penultimate section deals with issues related to robustness and timing of the delivery of media coverage, and Section VII concludes.

\footnotetext{
2 Indeed, numerous authors (e.g., Hong and Stein (2007)) have commented on the sharp distinction between the low (or even zero) volume predicted by seminal information theoretic models and that observed in practice.
} 


\section{Identifying Media Effects: An Example}

To illustrate the main identification problem, consider the following example. On November 9, 2007, the Detroit News ran a story about local firm DTE Energy that had reported third quarter earnings just the day before. The headline read 'DTE reports 3rd-quarter gains over '06 in earnings, revenue" and the story compared DTE's third quarter EPS of \$1.16 with the \$1.06 DTE earned a year earlier. On February 21, 2008, DTE released fourth quarter earnings of $\$ 1.56$ per share, compared with $\$ .80$ a year earlier. The Detroit News did not cover this second story. Although EPS was higher in both cases - and even more so in the second -overall trading volume was $21 \%$ higher in the three trading days after the first announcement, compared with the same interval after the second announcement.

This example is typical: many studies have found a correlation between media coverage and trading volume. However, this set of facts alone allows us to conclude little about causation, i.e., whether media coverage led to (even part of the) increased trading. It is certainly possible that the Detroit News's coverage or that of other media outlets altered investors' responses to the earnings event. On the other hand, it is possible that features surrounding the first event jointly determined the likelihood of coverage and the amount of trading.

To formalize the problem, suppose that the true model for investor demand D can be represented as

$$
D(X, M(X, Y)) \text {, }
$$

where $\mathrm{M}$ is media coverage, $\mathrm{X}$ is a set of characteristics that potentially determine both media coverage and investor demand, and $\mathrm{Y}$ is a set of characteristics that only influence media coverage. Both $\mathrm{X}$ and $\mathrm{Y}$ are public, but may be difficult to proxy with observable characteristics. Generally, the vector X could include firm or market fundamentals as well as investor sentiment or preferences. In our example, X might be DTE's earnings news or investor interest in DTE stock. By contrast, Y includes factors that influence the media's objective function, but otherwise have no influence on the behavior of traders. In our example, Y could be the Detroit 
mayor Kwame Kilpatrick's sex scandal that consumed the Detroit media during the time of DTE's fourth quarter earnings announcement in February. ${ }^{3}$

Because we are interested in how changes in media coverage (M) affect investor demand (D), we write the total derivative of $\mathrm{D}$ as:

$$
d D=\frac{\partial D}{\partial X} d X+\frac{\partial D}{\partial M} \bullet \frac{\partial M}{\partial X} d X+\frac{\partial D}{\partial M} \bullet \frac{\partial M}{\partial Y} d Y .
$$

The first term describes how investor demand varies in response to innovations in underlying events X, apart from any role played by the media. Presumably, investors can learn about and interpret changes in fundamentals through other channels including word of mouth, their own investigations, etc. As long as $\mathrm{X}$ is public, there is a strong theoretical foundation for prices incorporating this information quickly and completely. In practice, the main problem is that the econometrician does not observe X perfectly, and thus, cannot quantify the effect of the first term - the "pure" investor response to changes in underlying fundamentals.

The second term says that even though X is public, the media's "packaging" of it matters. Perhaps the most obvious reason that such packaging might matter is that investors have limited attention (Kahneman (1973)), and depend on media to alert them of innovations in X that would influence their decisions. In other words, the media makes "knowable" facts in X actually known. It is also possible that media outlets engage in biased reporting (Gentkow and Shapiro (2006)), or even fail to run a story that, if reported, would generate a trading response.

The final term specifies that the media can influence investors, even absent innovations in underlying events. For example, investors may simply mistake media stories for actual information events (note that the final term does not contain $\mathrm{X}$ ), as appears to be the case in Huberman and Regev (2001). We refer to terms two and three as "media effects," channels through which the media's activity has a causal impact on trader behavior.

\footnotetext{
3 http://www.newsweek.com/id/104993.
} 
The identification problem stems from the fact that although $\mathrm{X}$ jointly determines trading and media coverage, $\mathrm{X}$ is generally difficult to measure. Consequently, a regression of $\mathrm{D}$ on $\mathrm{M}$ (or proxies for $\mathrm{M}$ ) does not allow the econometrician to infer a causal relation. The goal of our analysis is to empirically separate the second and third terms - the "media effects" - from the first term, representing market reactions to underlying events.

Our basic assumption is that investor reactions to innovations in $\mathrm{X}$ are similar in the cross-section. Whatever DTE's 2008-Q1 earnings may imply about its prospects, it is difficult to envision why Houston and Denver investors would systematically interpret this information differently. To the extent that such similarity exists, we have controlled for the first term, reaction to the underlying event. However, supposing that the Denver Post reported DTE's earnings and the Houston Chronicle did not, we have identified a laboratory for identifying a media effect for Denver investors. This example summarizes our basic analysis.

The second part of the paper is concerned with the possibility that even this test is misspecified. Specifically, it remains possible that we may have missed unobserved elements of X that determine both trading and media coverage at the local level. For example, suppose that DTE planned to expand to San Francisco (it did not), based on its stellar earnings during the first quarter of 2008. Presumably, this fact is less relevant for Denver investors, which would explain the lack of interest both by the Post and on the part of Denver investors.

To address this, our most precise tests focus not on the coverage decisions of individual newspapers, but on factors that affect only the timing of delivery to investors. This is captured in the vector Y above, and might include things like a newspaper's print deadline (which would affect whether an event received late Wednesday is printed on Thursday or Friday). Such tests shut down completely any correlation between coverage and trading, other than through exogenous factors that cannot plausibly be related to both. 


\section{Data}

Our analysis requires data of three types: 1) earnings announcements, 2) local media coverage (around those earnings events), and 3) trading of retail investors.

We first collect all earning announcements dates from S\&P 500 firms between J anuary 1991 and December 2007. Earnings announcement dates and S\&P 500 membership are taken from COMPUSTAT. Because we are concerned about the appropriate timing of earnings announcement dates, we cross-check the dates in COMPUSTAT with those in I/B/E/S and only keep the dates in which they match. For each earnings announcement we calculate the earnings surprise (standard unexpected earnings, or SUE) based on the random walk model with price as the deflator (Livnat and Mendenhall (2006)).

We download our media coverage data from ProQuest's newspaper database. We have articles from the following cities (newspapers): Boston (Globe), Denver (Post), Detroit (News), Houston (Chronicle), Las Vegas (Review Journal), New York (Times), Pittsburgh (Post Gazette), San Antonio (Express News), San Diego (Union Tribune), San Francisco (Chronicle), Seattle (Post Intelligencer), St. Louis (Post Dispatch), St. Petersburg (Times), Minneapolis (Star Tribune), Atlanta (Journal Constitution), Sacramento (Bee), Washington (Post), and New Orleans (Times Picayune). We also collect data from two newspapers with national audiences: the USA Today and the Wall Street J ournal.

Articles about firms in ProQuest are indexed by company name. Using the COMPUSTAT firm name we manually match each S\&P 500 firm to its indexed firm name in ProQuest (some firms are linked to multiple ProQuest company names). Using the indexed firm names and the advanced search option in ProQuest, we search and download all articles in the newspaper database between 1991 and 2007 for each firm. ${ }^{4}$ The result is a database of newspaper articles linked by GVKEYs to S\&P 500 firms. When we say that a newspaper X "covers" firm Y's

${ }^{4}$ Some articles in ProQuest are full-text while others provide only the headline and a summary or abstract. 
earnings announcement, we mean that there is an article in newspapers $\mathrm{X}$ on day 0,1 or 2 after firm Y's earnings announcement in which firm Y is indexed by ProQuest in the article.

The trading data come from the well-known large discount brokerage database used by Barber and Odean (2000), with data available between 1991 and 1996. The database consists of the holdings and trading behavior of 77,795 households of which 54,297 have valid zip code information. Among those 54,297 households, 43,198 hold at least one common stock for which we have matched COMPUSTAT/CRSP information. Among those 43,198 households, 15,951 households are located within $100 \mathrm{~km}$ of any of our 19 local newspapers. Portfolio holdings are available monthly between January 31, 1991, and December 31, 1996, while account-level trading data are available between J anuary 1, 1991 and November 30, 1996. We use the trading data as the dependent variable in the majority of our tests, and use the holdings data when we consider investor predisposition to investing in certain stocks.

Table 1 provides some summary statistics from our data. Unsurprisingly, we have the largest sample of households with accounts in well-populated areas like San Francisco $(4,076)$, Los Angeles $(1,913)$ and New York $(2,808)$ with generally more accounts in the western United States (Zhu (2002)). However, we still have a considerable number of brokerage accounts in other major U.S. cities like Boston (635), Washington D.C. (983) and Houston (607). From the third column of the top panel in Table 1, we see that, given that a household holds common stock, the average number of stocks held is about 2 in every city. (Of course, this does not include mutual fund ownership or household holdings in other brokerage accounts.)

Table 1 also demonstrates a strong local bias in nearly every city. To measure local bias we pool the accounts of all investors in a city and compute the number of local stocks (within a 100-km radius of the local newspaper) held by this set; we then scale this number by the number of available local stocks (inferred from COMPUSTAT). We compute a similar statistic for nonlocal firms (non-local stocks held scaled by the available number of non-local stocks). Comparing the statistics for local and non-local stocks demonstrates a strong local bias that has 
been documented in other papers using the same database (Ivković and Weisbenner (2005), Seasholes and Zhu (2005) and Zhu (2002)). For example, the Minneapolis portfolio holds $21.8 \%$ of local stocks compared to 3.6\% of non-local stocks, and the San Francisco portfolio holds $44.4 \%$ of local stocks compared to $15.1 \%$ of non-local stocks.

Local papers also report disproportionately about local firms (Butler and Gurun (2009)). For example, Table 1 indicates that the San Antonio Express News covers 3.5\% of earnings announcements reported by non-local firms, but over $40 \%$ for those by firms located near San Antonio. This relationship holds for each of our 19 papers and, like the San Antonio example, the differences in frequency are often quite large. The paper exhibiting the least local bias is the New York Times, who reports the earnings of New York firms twice as often as those located remotely. The Times Picayune, at the other extreme, is over 100 times less likely to cover earnings of a firm located outside the New Orleans area.

\section{Local Trading Responses to Local Media}

The appeal of local media coverage is that it allows us to examine the behavior of traders subjected to different media coverage of the same information event. Presumably, this situation describes virtually every trader each time a piece of information is released into the market. However, almost never do we observe a given investor's information sources (television, radio, print media, internet, personal advice, etc.), and, even then, we often do not observe his or her responses. In aggregate data, this greatly limits our ability to make causal inferences about the media's influence on financial market participants.

Our empirical setting is fortunate in allowing us to identify specific groups of investors who are more (or less) likely to receive coverage by specific media outlets. Identification here relies on the assumption that an investor living in a given metro area is more likely to read the local newspaper than another regional paper (i.e., a different city's local paper). Importantly, identification does not require investors to rely solely on local papers for their financial 
information, although some may. More exclusive reliance on local media would increase the power of our tests, but is not necessary to achieve identification.

As seen in Table 1, the mean value of Local Media Coverage is only $2.8 \%$ (standard deviation of $16.6 \%)$, indicating that roughly one in thirty-five quarterly announcements is reported in local newspapers. By contrast, this is over an order of magnitude less frequent than the Wall Street J ournal, which accompanies an earnings release with a story or report $29 \%$ of the time in our sample (1991-1996) and 33\% of the time over the period 1991-2007.

\section{A. Methodology and Specification}

The relation between local media coverage and local trading is evident from simple correlations. On days in which earnings are reported in the local paper, the average absolute dollar volume of local trading in the mentioned stock is $\$ 2,200$. By contrast, the average local trading on "non-news" days at the local level is only \$290. While a sizeable difference, local trading is likely determined by a number of other factors, some of which may be correlated with local media coverage. Thus, in our main tests we estimate the following multivariate regression:

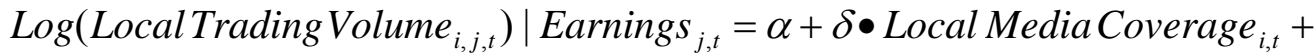

$$
\begin{aligned}
& \phi \bullet \text { Firm Attributes }_{i, t}+\zeta \bullet \text { Earnings Surprise }_{j, t}+ \\
& \gamma \bullet \text { Media Fixed Effects }{ }_{j}+\sigma \bullet \text { City Fixed Effects }+\varepsilon_{i, t}
\end{aligned}
$$

The dependent variable measures trading responses of retail investors in each of the nineteen local markets, i, to each S\&P 500 firm j's earnings released at time t. All local market are mutually exclusive, so that trading of firm j's stock may occur in local market 1 , but may not occur in local market 2, and so on. The goal of equation (1) is to understand what firm, media, investor, and earnings characteristics explain these cross-sectional differences in local trading behavior. 
The dependent variable is constructed over a three-day trading window, so that if firm j's earnings are released on Wednesday, local trading is recorded if it occurs on that Wednesday, Thursday, or Friday. In each specification of Table 2, the trading variable is the natural logarithm of one plus the absolute dollar trading volume in firm j's stock, aggregated across all investors (for which we have records) in region i within three days $(0,1$ or 2$)$ of the earnings announcement.

The main explanatory variable of interest is Local Media Coverage, which takes a value of one if region i's local newspaper reports firm j's earnings (also within three days of its announcement), and zero otherwise.

Crucially, Equation (1) also includes paper fixed effects for each of the nineteen local newspapers. This means that Local Media Coverage is identified solely from the differential responses between a newspaper's local readers and its non-local readership. For example, Media Fixed Effects includes a dummy variable for the Houston Chronicle that takes a value of one, for each of the nineteen local markets, whenever the Chronicle covers an earnings announcement. Because there are nineteen such dummy variables, each local paper is allowed to have a differential influence on trader behavior. However, only for the 1/19th of the observations corresponding to Houston investors does Local Media Coverage equal one, allowing the Houston paper to have an additional impact on those investors most likely to be exposed to the story (local investors).

We also include controls for media mentions in either of two national media: The Wall Street J ournal and USA Today. Both papers have national readership, and consequently, resist the linkage to specific investors that is possible for local papers. Nonetheless, their inclusion in our regressions control for any omitted correlation between local and national media, affording us the ability to uniquely identify media effects through local channels.

Other important control variables include Firm Attributes, which includes each firm's market capitalization (measured at the end of the most recent fiscal year) as well its Fama- 
French 30 industry classification. By clustering residuals by firm, we compute standard errors that allow for each firm i to have its own unobserved effect on the likelihood that a newspaper covers its earnings, and allow such firm-specific heterogeneity to change across time (Petersen (2009)). ${ }^{5}$ Some of our robustness tests (Table 7) include firm fixed effects, firm-city fixed effects, and other similarly constructed variables intended to capture unobserved heterogeneity.

The Earnings Surprise (SUE) control variables account for the fact that some earnings events lead investors to revise their expectations more than others, and therefore, are more likely to generate trade. To capture these differences, we calculate SUE as the difference between actual earnings and earnings four quarters ago divided by price (see Livnat and Mendenhall (2006) for a detailed discussion of SUE construction). We form quintiles of this surprise variable, after pooling all earnings announcements. ${ }^{6}$

\section{B. Results}

Table 2 presents the results of linear regressions of equation (1). The first and second columns include only firm clustering and date fixed effects. As seen, Local Media Coverage increases local trading volume in the typical market by almost 75\%. Column 2 adds industry controls and firm size, and although larger firms are associated with more trading $(p=.000)$, this has only a trivial effect on both the economic and statistical significance of Local Media Coverage.

Controls for the magnitude of the Earnings Surprise reveals an intuitive finding. The omitted dummy is the middle quintile of "least surprising" earnings announcements, relative to

\footnotetext{
${ }^{5}$ Clustering by firm allows standard errors to be correctly computed in the presence of a firm fixed effect or a temporary effect (e.g. a firm effect which decays over time). In unreported results, we also find that the inclusion of firm fixed effects to the estimation of equation (1) makes no qualitative difference in our results.

${ }^{6}$ The results are unchanged if we use alternative ranking criteria, such as within-industry, within industry-year, and forming deciles rather than quintiles. The results are also unchanged is we use a definition of earnings surprise based on the median analyst forecast (rather than the random walk model).
} 
the earnings four quarters ago. Column 3 indicates that trading is highest following the most surprising earnings events, both positive and negative. Both coefficients on $\mathrm{SUE}_{1}$ and $\mathrm{SUE}_{5}$ suggest increases in trading volume of about 7-8\%, both effects highly significant. In contrast, those corresponding to less extreme earnings surprises, $\mathrm{SUE}_{2}$ and $\mathrm{SUE}_{4}$, are much less statistically and economically significant. A rational interpretation is that SUE captures an investor's surprise about cash flows, so that $\mathrm{SUE}_{1}$ and $\mathrm{SUE}_{5}$ events are associated with significant portfolio rebalancing; it is also consistent with a number of behavioral explanations. In either case, the coefficient of interest on Local Media Coverage remains essentially unchanged.

In unreported results, we have also run a number of regressions with an analyst-based definition of earnings surprise (Livnat and Mendenhall (2006)) and finer breakpoints, e.g., deciles instead of quintiles. The magnitude on any SUE variable never exceeds 0.15 in any regression specification. In other words, when we compare the effect of the information in SUE with the effect of media coverage (Local Media Coverage), the media effect is consistently three to ten times larger than the information effect. At least for retail investors, demands appear far more sensitive to media coverage than to the underlying information.

While SUE is a conventional way to measure how surprising an earnings event is, there may be many other salient pieces of information also disclosed at the earnings announcement date that affect trading. To capture newsworthy earnings announcements, Column 4 includes a dummy variable for each of the nineteen local and two national media outlets, allowing them to affect trading in any market. The marginal effects shown for each paper are relative to the benchmark case when neither a local nor national media outlet covers the earnings announcement. ${ }^{7}$ As seen, most coefficients for these individual papers are not statistically different from zero, indicating that most have only a trivial effect on their non-local investor

\footnotetext{
${ }^{7}$ Note that the "dummy trap" does not apply among the set of newspaper fixed effects, as they do not constitute a mutually exclusive set.
} 
community. The few exceptions include The New York Times and the San Francisco Chronicle, newspapers widely read outside of their immediate catchment area.

In the final column of Table 2, we include fixed effects for each of the nineteen local markets, allowing average trading volumes to vary across cities. This set of controls is clearly important, increasing the $\mathrm{R}^{2}$ by almost 2 percentage points. The results here are intuitive. We see that relative to investors in Denver (the arbitrarily omitted city), local trading volume is higher in larger markets such as Boston, Houston, New York, San Francisco, and San Diego, and is lower in smaller ones such as Las Vegas, San Antonio, and St. Louis. Moreover, with such city controls, the coefficient on Local Media Coverage is now identified purely off of differences-indifferences between city-newspaper pairs. That is, the coefficient on Local Media Coverage picks up only the average marginal impact of the media source being local, not the average effects due to larger cities, more influential papers, etc. Taking the final column as the most indicative of the underlying behavior, local media is associated with a $48 \% \%$ increase in trading activity.

The estimates in Table 2 are presented for all transactions lumped together. In Table 3, we disaggregate them, showing the results for buys and sells separately in Panels A and B respectively. A priori, one might expect the effects to be stronger on the buying side, given the evidence that retails investors are unlikely to sell stocks short (Barber and Odean (2008)). If retail investors do not sell short, then they can only sell when they hold the stock, and thereby presents fewer occasions upon which to respond negatively to local media coverage.

As expected, the coefficients in this table approximately sum to those in the previous table. However, Panel A shows that although buying is responsible for more than half of all trading activity, with coefficients ranging from .46 (column 1) to 0.29 (column 5), the disparity over selling activity is small. In Panel B, we observe slightly lower magnitudes (.38 to .26) for the selling/shorting regressions, but Local Media Coverage remains highly significant in each 
specification. Table 3 shows clearly that the effects of the media, at least the local media, are pervasive across both additions and subtractions to investors portfolios.

\section{Endogeneity of Media Coverage}

The primary advantage of our cross-sectional approach is that by construction, it eliminates the typical concern that reactions to underlying events, rather than media coverage, is driving the result. In this section, we discuss a second type of endogeneity particularly relevant for analysis of local coverage. Specifically, because we are analyzing a number of local newspapers that likely cater to the interests of local investors, the possibility arises that local media may simply reflect, rather than cause the trading patterns we observe. For example, consider the hypothetical case where a local newspaper polls its readers, asking of them which stocks they would like the paper to cover. If the paper heeded these suggestions, then the observed correlation between local coverage and local trading would not be spurious, but the causation would run in the reverse direction.

Fortunately, our data are well suited to address this possibility. The analysis in this section is organized into three parts. First, we collect a number of additional control variables designed to measure each local market's pre-existing interest in certain stocks. As we will see, many of these measures are very precise, allowing us to argue that any remaining relation between trading and media coverage can be interpreted in the desired (causal) way. Our second and third tests allow for even more precise identification. We identify two characteristics that cause interference with the transmission of media coverage to investors, but leaves unchanged both any underlying content (e.g., information, media spin), as well as the pre-existing demands

of investors. As we will see, such exogenous variation strongly predicts trading, posing a significant challenge to alternative interpretations. 


\section{A. Local Demand}

Our first set of tests is motivated by the observation that both retail and institutional investors appear to tilt their portfolios toward geographically local stocks at the expense of their remote counterparts (Coval and Moskowitz (1999, 2001), Ivković and Weisbenner (2005), Zhu(2002), Seasholes and Zhu (2005)). Regardless of why such "home bias" exists, the concern is apparent. ${ }^{8}$ In addition to being more widely held by local investors, local firms are more likely to be covered by local newspapers. Thus, what we interpret causally as a media effect may reflect little more than the tendency of both local papers and local investors to pay attention to local stocks.

To address this possibility, for each of the nineteen regions i, we augment equation (1) to include a dummy variable indicating whether firm j's headquarters is within $100 \mathrm{~km}$ of the local newspaper. ${ }^{9}$ This designation allows us to identify stocks likely to be of particular interest to each cohort of local investors. Confirming the home bias found in previous studies, we find that investors are more likely to both hold ( $0.43 \%$ vs. $0.16 \%)$ and trade $(9.9 \%$ vs. $2.0 \%)$ the stocks of local firms following earnings announcements. Local coverage is tilted even more toward local firms (19.2\%vs. $2.7 \%)$.

Even so, column 1 of Table 4 indicates that even when all local firms $(<100 \mathrm{~km}$ of the paper's headquarters) are excluded, Local Media Coverage remains strongly related to local trading. Here, the thought experiment is to compare the trading patterns between a Houston and San Antonio investor, after Ohio-based Proctor and Gamble (P\&G) releases its quarterly earnings. From the perspective of each investor, P\&G is a non-local firm, with headquarters removed by over 1,000 miles from each. However, if the Houston Chronicle reports P\&G's earnings while the San Antonio Express News does not, trading volume in Houston increases by

8 Coval and Moskowitz (1999, 2001) argue for an information-based explanation of the home bias among institutional investors. Ivković and Weisbenner (2005) make a similar argument for retail traders. Zhu(2002) and Seasholes and Zhu (2005) provide a behavioral explanation of the home bias of retail traders based on familiarity.

${ }^{9}$ Alternative breakpoints (e.g., $200 \mathrm{~km}, 500 \mathrm{~km}$ ) give nearly identical results. 
28.3\% relative to its normal volume, while no similar increase is seen in San Antonio. The second column presents this analysis in a slightly different way, including a dummy variable for a local firm, and returns to the original, full sample. Adding this variable permits us to observe a "local firm effect" of nearly 50\%, confirming the previous findings of (Ivković and Weisbenner (2005), Zhu(2002), Seasholes and Zhu (2005)), who document a home bias for retail traders using the same database. However, our primary interest is in the Local Media Coverage variable; the second column reveals that it strengthens slightly to over .3, and remains highly significant.

The third and fourth columns consider more precise proxies for the pre-existing demands of local traders. Although a firm's geographic proximity may influence an investor's willingness to hold or trade its stock, other factors may generate cross-region differences in investor interest. For example, it would be unsurprising for investors in St. Louis (home to beer bottler Anheuser-Busch during our sample period) to be interested in the fortunes of other brewers or distillers, even those located remotely. Similar arguments can be made for other cities, whose investors may cluster along certain stocks or industries. If local media outlets understand such preferences, and consider them in their coverage decisions, then the same identification remains - media coverage may simply reflect existing investor interest rather than cause it.

To address this concern, we examine the individual portfolio holdings of each investor within each of the nineteen local markets. This exercise allows us to identify stocks likely to be traded in each market, based directly on which stocks are already held or frequently traded. For each region $i$, we construct two additional local variables, for stock $\mathrm{j}$ : 1) the fraction of investors within region $\mathrm{i}$ that own stock $\mathrm{j}$ at the beginning of the trading month, and 2) the fraction of investors within region $\mathrm{i}$ that traded stockj the previous month.

The third column shows the results of the regression, once we add the first control variable. As seen, although Fraction Locally Held is observed as being strongly related to local 
trading, its inclusion actually strengthens the local media variable, which remains highly significant. The fourth column is similar, except that Fraction Locally Traded is the key control variable. It has a similarly strong effect (as expected), although the coefficient on Local Media Coverage remains strong. The final column includes all three controls for pre-existing local demand simultaneously, which shows an $\mathrm{R}^{2}$ of over $8 \%$, some fifty percent larger than the base regression in the final column in Table 2 . The increase in explanatory power, along with the extremely high significance of each control, suggests that we have controlled for a large portion of the pre-existing local demand for each stock $j$ and region $i$. If so, then the coefficient on Local Media Coverage (roughly 28\%) represents the pure effects of media coverage.

In unreported results, we have conducted a number of robustness checks similar to the ones reported here. For example, varying the definition of a "local" firm (e.g., 200 km, 500 km) makes very little difference. Similarly, other unreported results, we have experimented with a number of alternatives, including longer time periods, e.g., averaging the fraction of local investors that hold a given stock over several months up to a year, using dummy variables instead of continuous variables in the regressions, etc. None make any meaningful difference.

\section{B. Extreme Weather and Transmission of Media Content}

The strategy in the previous section was to control explicitly for each market's existing demand for certain securities, so that any remaining relation between trading and media can be interpreted causally. Here, we attempt to achieve identification through different means. The goal of this analysis is to find exogenous variation in the transmission of media stories to investors, but crucially, to leave both the content of the media story and the demands of local traders constant. Moreover, we look for high-frequency variation, which is particularly convenient in attempting to hold constant investor demands, which may change over time.

In our search for exogenous variation in the dissemination of media content to investors, we are aided by the fact that our sample period (1991-1996) is largely pre-Internet. This implies 
that in contrast to the modern electronic era: 1) printed content had to be processed and transferred to an actual printed media (the paper), and 2) the printed newspaper needed to be physically delivered, usually door to door by a delivery person, or more likely, a "paper boy." Disruptions in either step would delay or prevent altogether media content from reaching investors, but because both are unrelated to either the content or investor demand for financial securities, they represent the ideal type of exogenous variation that makes identification feasible.

Our first source of variation is extreme weather. For each of our nineteen local markets, we collect weather data. Weather data are taken from the National Climatic Data Center at ftp://ftp.ncdc.noaa.gov/pub/data/gsod, which provide daily data for each weather station as well as the coordinates (longitude and latitude) of each station. For each trading area, we use weather from the station closest to the local newspaper's zip code. The weather data include high and low temperatures, inches of snow, precipitation and indicators of extreme weather.

From these data, we identify two types of weather events likely to impede or significantly delay delivery of the local, daily newspaper: hailstorms/ freezing rain and blizzards. Following Loughran and Schultz (2004), we define a Blizzard as greater than or equal to eight inches of new snow, although other definitions give similar results. Blizzard and Hail are both dummy variables that take a value of one if the extreme weather occurs on either the earnings announcement day or that immediately proceeding. Extreme weather events, as expected, are clustered in the Northeast and Midwest (e.g., Boston, Minneapolis, Detroit). Across all markets, we identify 736 observations that include a Blizzard, and 1,188 that include Hail. There is one overlap, so their union, Extreme Weather, includes 1,923 observations.

The first column of Table 5 shows the results of estimating (1), with two addition variables: the Hail variable and Hail*Local Media Coverage. The full set of controls from the final column in Table 2 is deployed. With the presence of the interaction term, the coefficient on Local Media Coverage now corresponds to the effect of local media on local trading on days without Hail. As 
seen, this is nearly identical to the baseline case, shown the final column of Table 2 , with a point estimate of $0.48(\mathrm{p}=0.000)$. As seen, the presence of Hail does not have a meaningful impact on local retail trading; only the weakest inference can be made regarding the positive point estimate $(p=17)$. However, we are interested in the sign on the interaction term, which is negative and highly significant, even more so than the original Local Media Coverage coefficient itself. This indicates that on extreme weather days, the relation between media coverage and trading is severed entirely.

Importantly, the interaction here has nothing to do with Hail lowering the probability of local financial reporting, because indicators for mention in each of our twenty-one papers are still included. Instead, the negative sign on the interaction demonstrates that local media content pertaining to the firm of interest, on days when it is unlikely to be delivered to local investors, has no effect on trading. This finding, we argue, isolates precisely a media effect - it holds the underlying information constant (as do our previous regressions), but also keeps constant the unobservable demands of local traders.

The second column presents the same analysis, except for our second type of extreme weather, Blizzards. The findings and their interpretation are nearly identical. We see that Blizzards alone are not observed to be associated with local retail trading. That is, on days where the local paper doesn't report any news about the firm of interest (recall that the presence of the interaction leads to this interpretation of Blizzards), the presence or absence of a Blizzard makes no difference on trading decisions. ${ }^{10}$ However, the interaction is, as above, strongly negative, more than offsetting the positive effects of Local Media Coverage. The final column aggregates all instances of Extreme Weather, and delivers nearly identical results. On days when the delivery of local news is exogenously delayed or prevented, investors do not respond to

\footnotetext{
${ }^{10}$ Note that this finding implies at least some reliance on local newspapers for financial information. Instance of extreme weather (e.g., Blizzards and Hail) are temporary disruptions in the delivery of local news sources, but are unlikely to be correlated with, for example, weekly subscriptions to financial magazines. The fact that inclement weather only dampens trading on days when local papers report news thus suggests that local papers fill this function for at least some retail investors.
} 
any content. This evidence strongly suggests that the media is not passively correlated with a pre-existing relation between local trading and the information contained in media reports.

\section{Robustness and Timing}

In this section, we consider a number of robustness issues, related to how we measure local trading, as well as how we control for unobserved heterogeneity in the determinants of local trade.

\section{A. Alternative Definitions of Local Trade}

In Table 6, our aim is to reduce the potential for a few large orders to generate the results we find. Instead of trading volume, in the first three columns we alternatively define as the dependent variable the natural logarithm of the number of local accounts that trade the stock of interest. This in turn changes the interpretation of the local media coefficient. Instead of the percentage change in absolute trading volume, the coefficient on Local Media Coverage represents the increases in the number of local traders who trade, regardless of the size of their order.

The first column, for example, indicates that mention in the local newspaper increases by approximately $4.67 \%$ the number of accounts trading the stock of interest within three days of its earnings being locally reported. The mean number of households in each local market is 840 (standard deviation=1028), ranging from only 134 accounts in New Orleans to 4,078 in the San Francisco Bay Area. Thus, local news mentions affect, on average, as few as two traders $(4.67 \% * 37=1.7)$ to well over one hundred. The second and third columns paint a similar picture to Table 3; both the percentage change in the number of "buyers" or "sellers" orders are significantly related to Local Media Coverage, and in approximately equal magnitudes.

The next specification, shown in the final three columns, reduces further any residual size effects. Here, we map the underlying trading behavior to a discrete representation. The 
dependent variable takes a value of one if there is any local trading in the stock corresponding to the earnings announcement, regardless of either the number of traders or size of their trades. For example, suppose that after IBM released its earnings on a given date, and that the following day one hundred traders in San Francisco traded some $\$ 100,000$ worth of IBM stock, while in New Orleans, only two trades summing to $\$ 500$ are observed. Despite the substantial size differences, the dependent variable takes a value of one in each case. As before, all estimates here include the full assortment of control variables, as shown in the final columns of Tables 2 and 3.

Columns 4-6 of Table 6 show the results of linear probability models for the discrete variable specification (although probits present similar estimates). ${ }^{11}$ As in column 1, column 4 aggregates all transactions together, indicating that Local Media Coverage increases the probability of observing any local trade by about 5\%. The second and third columns break up this effect into buy and sell transactions where, also as before, the effect is relatively equal between the two, and highly significant.

\section{B. Controlling for Unobserved Heterogeneity}

The various sets of control variables employed in Tables 2 through 6 attempt to control for any simultaneous determinants of local media coverage and local trading. Underlying these regressions is the OLS consistency assumption: after the inclusion of these controls, a media's decision to report an earnings announcement is unrelated to local trading. The plausibility of this assumption is, of course, difficult to judge for the same reasons that an identification problem exists at all. In general, we never perfectly observe the complete set of determinants expected to influence local coverage and trading decisions.

In Table 7, rather than attempt to control for these with observables, we include large sets of fixed effects to sweep out such unobserved heterogeneity. Recalling that our unit of

\footnotetext{
11 We use the LPM specification to accommodate the large number $(1,350)$ of date fixed effects in our sample.
} 
observation is defined at the city-earnings date-firm level, we can still estimate equation (1) with fixed effects for any pairwise combination of these. For example, city-firm pair fixed effects accounts for time invariant relation between a given city's investor group and a given firm. Obviously, this accounts for any home bias, but is considerably more general.

The first column shows the result when firm-earnings date fixed effects are included, along with the complete set of controls employed in the final column of Table 2. Given that date effects were already present, the addition of firm-date dummies simply allows for trading in any market to depend on a given firm at a given time. This obviously subsumes the SUE variables, and controls for any unobserved events that influence a firm's cross-sectional appeal to local traders. However, as seen, this set of controls makes very little difference, with the coefficient on Local Media Coverage being almost identical to the final column in Table 2.

The second column of Table 7 include firm-city dummies, and while still highly significant, the magnitude on local coverage is cut by nearly sixfold. This is unsurprising, given that in Table 4 we saw that a city's past trading activity in a stock strongly predicts future trading. Nonetheless, it is striking that even for a given firm-city combination, a local trader's exposure to the firm's events strongly predicts additional trading. The final column shows the results when we include fixed effects for each city-earnings date. As seen, this given very similar estimates to both the first column of Table 7, and to the final column of Table 2.

We include each of the pairwise fixed effects in the final column, and therefore identify media effects net of city-firm, city-date, and firm-date fixed effects. The magnitude of the coefficient indicates an $8 \%$ increase in local trading activity, after sweeping out the unobserved determinants of trading and coverage captured in the fixed effects. Although the magnitude falls sharply (from $47 \%$ to $8 \%$ ) when city-firm fixed effects are included, the purpose of Table 7 is identification rather than specification of the true underlying model. For example, suppose a newspaper covers every earnings announcement of its favorite firm. Even if this was the reason 
trading volume for the firm was high in the newspaper's city, including a city-firm fixed effect will mask this causal relationship.

\section{Timing of Media Stories and Timing of Trading}

Our final test identification builds upon the results in Table 7, and like the weather tests in Table 5, exploits a second source of exogenous variation in the transmission of media coverage to investors - a newspaper's "time-to-print." In contrast to the modern, electronic information age when web-based news outlets can collect and disseminate stories in hours or minutes, in our time period, print newspapers require substantial lead time in order for information on day $t$ to be printed on day $t+1$. Fortunately, this requirement introduces a further source of variation that is, in theory, perfectly uncorrelated with either firm-side or investor-side determinants of trading decisions.

We do not observe individual papers' deadline times, and even if we did, we do not observe the exact times when firms release earnings. However, we can infer the necessary information from the empirical distribution of earnings dates and story dates. We are specifically interested in whether micro-variation (e.g., over one day) across local papers predicts similar micro-variation in local trading. For example, if San Diego's Union Tribune reports Home Depot's earnings on Tuesday, and the Boston Globe reports it on Wednesday, do we observe abnormal trading volume of Home Depot in San Diego on Tuesday, and abnormal trading volume in Boston on Wednesday? Like the tests of extreme weather tests, such idiosyncratic, high frequency variation is difficult to claim as correlated with unobserved determinants of local trading.

To conduct this analysis, we take the sample of all earnings announcements, and determine whether the first local report (if it exists) ran on the same day of the release (t), the day immediately following $(t+1)$, or the day after that $(t+2)$. Then, we take each of the nineteen 
markets, and separate local trading into that occurring on day $t$, day $t+1$, or day $t+2$. The question we wish to answer is whether a newspaper's decision to run an earnings story of any particular day, say on day $t+2$, predicts trading on that particular day.

The data reveal substantial variation across newspapers in the time between earnings announcements and news coverage. About $40 \%$ of reported stories are broken on day $t$, about $50 \%$ on day $t+1$, and the balance on $t+2$. However, this ratio differs considerably by newspaper. For example, papers on the West Coast have the benefit of a later time zone (PST), and would be expected to "pick up" late day announcements more easily than their peers on the East Coast. For example, the $t+1$ to $t+2$ ratio for three large PST newspapers, the Seattle Post Intelligencer, San Francisco Chronicle, and Los Angeles Times is 4.25, 3.63, and 4.75 respectively. By comparison, the same ratios for the EST New York Times, Atlanta J ournal Constitution, and Pittsbrugh Post Gazette are 3.09, 2.76, and 3.81 respectively. However, there are presumably paper-specific issues unrelated to time zones that also influence deadlines. ${ }^{12}$ Regardless of the reason, our tests simply require that such differences be exogenous to the underlying content, as well as to local investor preferences for certain stocks.

In Table 8, we show three separate regressions for each of the three days following an earnings release. Each of the regressions includes the three pairwise fixed effects from the final table in Table 7, the most stringent set of controls allowable given the city-earnings date-firm unit observation. The first column shows that when attempting to predict trading on day $t$, only coverage on day $t$ matters. Neither coverage on future dates $t+1$ or $t+2$ are related to day $t$ trading, with point estimates roughly one-third of the standard error. On the other hand, simultaneous news coverage $(\mathrm{t})$ is strongly related to local trading, with a magnitude of roughly $9 \%$, virtually identical to the magnitude in Table 7.

This result is important for assessing model mis-specification. If, instead, we had found that future coverage - in this case, coverage on either days $t+1$ or day $t+2-$ predicted day $t$

12 For example, the San Diego Union Tribune has the highest percentage of stories reported on day $\mathrm{t}+2 \mathrm{in}$ our sample, despite being located on the West Coast. 
trading, this would be strong evidence of model mis-specification. One could imagine, for example, that even after city-firm fixed effects, there could be particular earnings announcements of special relevance for some cities. Note that this is not accounted for in either city-date or firm-date fixed effects, as the concern would require the union of a particular city, a particular date, and a particular firm.

However, this criticism is about the newspaper's coverage decision, and is unlikely to be related to single-day variation around its reporting date. This assumption allows us to simultaneous test for causal media effects (by looking for same-day correlation between reporting dates and trading) and for model mis-specification (by looking for a lack of correlation between trading and reporting on future days).

The second column repeats the same analysis, but considers only trading one day after the firm's earnings release. Here, we have the opportunity to test not only for mis-specification by allowing future media coverage to affect trading, but also to check for lagged effects by looking at past media coverage. Neither is seen to matter, although a significant coefficient on day $\mathrm{t}$ would not be evidence of mis-specification, but instead delayed reaction to media coverage. The final column considers trading two days after the earnings release, and confirms the evidence of the previous two columns. As before, only local media coverage on day $t+2$ predicts local trading on $t+2$. Unless such micro-variation is correlated with high-frequency changes in local investor demand, this result shows strong evidence that media activity can influence the behavior of investors.

\section{Conclusion}

We exploit the geographic variation of local paper readership to design and implement empirical tests allowing the media's effect on investors to be identified, distinct from responses to the underlying events. Analyzing the simultaneous reactions of investors in nineteen local markets to the same set of information events (earnings releases of S\&P 500 Index firms), we 
find that the presence or absence of local media coverage is strongly related to the probability and size of local trading. Although we would expect for stories reported by local newspapers to reflect the investment interests of local readers, this alone does not reconcile the evidence. When we examine the individual portfolios of each local investor, we find that the local media coverage-local trading relation remains strong for non-local firms, as well as for those sparsely held or traded by investors in the local market.

Perhaps the strongest causal evidence comes from examining exogenous shocks to the transmission of media coverage to local investors. On days when extreme weather (hailstorms and/or blizzards) is likely to disrupt the normal delivery of daily newspapers, the link between media coverage and trading is broken. This is an important test, because weather shocks are neither correlated with any underlying content, nor with unobservable determinants of investor demand. A complementary test takes advantage of small (one or two day) differences between days in which earnings stories are carried by newspapers, presumably because of differences in time zones, printing technology, and so forth. We find that trading patterns are strongly related to the local patterns of media coverage. For example, an earnings reported by the San Francisco Chronicle on Wednesday stimulates trade in the Bay Area on Wednesday; the entire set of events is shifted in Atlanta if the J ournal Constitution reports the same event Thursday. This pair of tests is difficult to reconcile with alternatives to a pure media effect on financial market participants.

The cross-sectional nature of our empirical design largely eliminates the usual omitted variable concern; however, the corresponding improvement in identification is not free. By carving up the trading space into small regions (recall that the unit of observation is defined by firm-date-city triple), we have hampered the ability for any one group to directly influence aggregate market outcomes. To see this, consider that our largest local market is the San Francisco Bay Area, for which we observe the actions of some 4,000 individual investors. But on any given day, most of these are not active, even less so any particular stock. Considering 
that our universe is the set of large, liquid firms comprising the S\&P 500 Index, and it is clear that we cannot link our results directly to prices, liquidity, etc.

On the other hand, it seems equally clear that the effects we identify at the local level should apply generally, i.e., to national media outlets with audiences large enough to meaningfully impact capital allocation. Specifically, beginning with Tetlock (2007) and Tetlock et al. (2008), a number of papers have shown that news stories in national newspapers are associated with substantial price responses. Here, identification usually focuses on what kind of information a story conveys - i.e., about a firm's cash flows, risk or sentiment. Less explored is the possibility that the story's very existence - a media effect - may generate a response independent of these channels. One could imagine, for example, decomposing the "news response coefficients" estimated in such studies into "media effects" and "content effects."

While we stop short of formally attempting such a decomposition, we can say something about their relative sizes. Throughout our tests we have included the earnings surprise (SUE) as a control in the regression, and we find extreme earnings surprises are related to the volume of retail trade. However, the media effect we identify is several times larger than this information effect no matter how we define our earnings surprise. Simply put, in our setting, media is much more likely to drive trade than information.

If this generalizes even partially to the national level, our results are clearly relevant for how we interpret the market's response to news stories. Moreover, our results call for careful research meant to better understand the incentives of financial media and the genesis of media coverage. If media effects are substantial, we should understand how they come about. First, given that firms manage access to their managers, how do the incentives of journalists affect the favorability of their reporting? Butler and Gurun (2009) and Reuter and Zitzewitz (2006) provide evidence that firms and mutual funds can tilt media coverage in their favor by purchasing advertizing space, indicative of a broad class of incentive problems (Dyck and Zingales (2003)). Second, as media have become increasingly electronic, the number of media 
sources has grown exponentially. How does this increasing competition over finite sources affect the quality of coverage? Third, given that information producers like analysts and institutional investors hold valuable private information about firms, how does the relationship between information producers and journalists affect media coverage? Some work along these lines has begun (e.g. Dyck, Volchkova and Zingales (2008)), but more is needed.

Nevertheless, the point of departure for each of these inquiries is that media coverage matter for investor behavior. The tests herein are the first to link individual investors to their respective media sources and therefore provide conclusive evidence that media effects are real and substantial. 


\section{References}

Barber, B., \& Odean, T., (2000). Trading is hazardous to your wealth: the common stock investment performance of individual investors. J ournal of Finance, 55 (2), 773- 806.

Barber, B., \&Odean, T., (2001). Boys will be boys: gender, overconfidence, and common stock investment. Quarterly J ournal of Economics, 116 (1), 261- 292.

Barber, B., \&Odean, T., (2008). All that glitters: The effect of attention and news on the buying behavior of individual and institutional investors, The Review of Financial Studies, 21, 785- 818.

Butler, A., \& Gurun, U. (2009). Don't believe the hype: local media slant, local advertising, and firm value. Working Paper. University of Texas at Dallas.

Campbell, J ., Grossman, S., \&Wang, J . (1993). Trading volume and serial correlation in stock returns, Quarterly J ournal of Economics, 108, 905-939.

Chan, W. (2003). Stock price reaction to news and no-news: Drift and reversal after headlines. J ournal of Financial Economics, 70(2), 223-260.

Coval, J ., and T. Moskowitz, 1999, Home Bias at Home: Local Equity Preference in Domestic Portfolios, J ournal of Finance 54, 2045-2073.

Coval, J., and T. Moskowitz, 2001, The Geography of Investment: Informed Trading and Asset Prices, J ournal of Political Economy, 109, 811-841.

DellaVigna, S., \& Kaplan, E. (2007). The Fox News effect: Media bias and voting. Quarterly J ournal of Economics, 122(3), 1187- 1234.

Dyck, A., \&Zingales, L., (2003). The Media and Asset Prices, Working Paper. HBS and University of Chicago.

Dyck, A., Volchkova, N., \&Zingales, L., (2008). "The corporate governance role of the media: Evidence from Russia," J ournal of Finance, 63(3), 1093-1135.

Fang, L. and J . Peress, (2009). Media coverage and the cross-section of stock returns, J ournal of Finance. forthcoming. 
Gentzkow, M., \& Shapiro, J . (2004). Media, Education, and anti-Americanism in the Muslim World. J ournal of Economic Perspectives, 18(3),117- 133.

Gerber, A., Karlan, D., \& Bergan, D. (2009). Does the media matter? A field experiment measuring the effect of newspapers on voting behavior and political opinions. American Economic J ournal: Applied Economics, 1(2), 35-52.

Hong, H. and \& Stein, J . (2007), Disagreement and the stock market. J ournal of Economic Perspectives $12,109-128$.

Huberman, G., \& Regev, T. (2001). Contagious speculation and a cure for cancer: A nonevent that made stock prices soar. The J ournal of Finance, 56(1), 387-396.

Huberman, G., \& Regev, T. (2001). Contagious speculation and a cure for cancer: A nonevent that made stock prices soar. The J ournal of Finance, 56(1), 387-396.

Ivković, Z., \&Weisbenner, S. (2005). Local does as local is: information content of the geography of individual investors' common stock investments, J ournal of Finance, 60, 267-306.

Loughran, T. and P. Schultz, 2004, Weather, Stock Returns, and the impact of localized trading behavior, J ournal of Financial and Quantitative Analysis 39, 343-364.

Livnat J., \& Mendenhall, R. (2006). Comparing the post-earnings announcement drift for surprises calculated from analyst and time series forecasts, J ournal of Accounting Research, 44, 177-205.

Massa, M., \& Simonov, A. (2006). Hedging, Familiarity and Portfolio Choice”, Review of Financial Studies, 19 (2), 633-685.

Mayew, W., \& M. Venkatachalam. (2008). The Power of Voice: Managerial Affective States and Future Firm Performance. Working Paper, Duke University.

Merton, R. (1987). A simple model of capital market equilibrium with incomplete information, J ournal of Finance, 42, 483-510.

Miller, G. S. (2006). The press as a watchdog for accounting fraud. Journal of Accounting Research, 44(5), 1001-1033.

Morris, S., \& Shin, H. (2002). Social value of public information. American Economic Review, 92(4), 1521-1534. 
Mullainathan, S., \& Schleifer , A. (2005). The market for news. American Economic Review, 95(4), 1031-1053.

Odean, T., (1998). Are investors reluctant to realize their losses? J ournal of Finance, 53 (5), 1775- 1798.

Odean, T., (1999). Do investors trade too much? American Economic Review, 89 (5), 1279- 1298.

Peress, J . (2008). Media coverage and investors' attention to earnings announcements, Working Paper. INSEAD.

Petersen, M. (2009). Estimating Standard Errors in Finance Panel Data Sets: Comparing Approaches, Review of Financial Studies. Review of Financial Studies, 22, 435- 480.

Reuter, J ., \&Zitzewitz, E. (2006). Do ads influence editors? Advertising and bias in the financial media. Quarterly J ournal of Economics, 121(1), 197-227.

Seasholes, M., \&Zhu, N. (2005). Is there information in the local portfolio choices of individuals? Working Paper. UC Davis.

Stromberg, D. (2004). Radio's impact on public spending. Quarterly J ournal of Economics, 119(1), $189-221$.

Tetlock, P. (2007). Giving content to investor sentiment: The role of media in the stock market. The J ournal of Finance, 62(3), 1139-1168.

Tetlock, P., Saar-Tsechansky, M., \&Macskassy, S. (2008). More than words: quantifying language to measure firms' fundamentals, J ournal of Finance, 63, 1437-1467.

Tetlock, P. (2009). All the News That's Fit to Reprint: Do Investors React to Stale Information? Working Paper. Columbia University.

Veldkamp, L. (2006). Media frenzies in markets for financial information. American Economic Review, 96(3), 577-601.

Zhu, N. (2002). The local bias of individual investors. Working Paper. UC Davis. 


\section{Table 1: Summary Statistics}

Account and trading data are taken from the large discount brokerage database with demographic information in Barber and Odean (2000). Accounts in Area is the number of accounts within 100 kilometers of the city's local paper headquarters. Local stocks are stocks of firms within 100 kilometers of the city's local paper headquarters. A paper "covers" an earnings announcement in our sample if a story about that firm appears on day 0,1 or 2 after the firm's earnings announcement in the ProQuest database. Earnings announcement dates are taken from COMPUSTAT and confirmed with I/B/E/S. $\operatorname{Pr}($ covering a non-local EA) is the frequency in which that paper covered a non-local earnings announcement. $\operatorname{Pr}($ covering a local EA) is the frequency in which that paper covered a local earnings announcement.

\begin{tabular}{|c|c|c|c|c|c|c|}
\hline & \multicolumn{4}{|c|}{ Accounts } & \multicolumn{2}{|c|}{ Paper } \\
\hline & Households in Area & $\begin{array}{l}\text { Avg \# of stocks } \\
\text { held }\end{array}$ & $\begin{array}{l}\text { Local Stocks Held / } \\
\text { Local Stocks Avail }\end{array}$ & $\begin{array}{l}\text { Non-Local Stocks Held } \\
\text { / Non-Local Stocks } \\
\text { Avail }\end{array}$ & $\begin{array}{c}\operatorname{Pr} \text { (covering a local } \\
\text { EA) }\end{array}$ & $\begin{array}{l}\operatorname{Pr} \text { (covering a non- } \\
\text { local EA) }\end{array}$ \\
\hline Atlanta (J OURNAL-CONSTITUTION) & 398 & 2.35 & 0.135 & 0.035 & 0.716 & 0.019 \\
\hline Boston (GLOBE) & 635 & 2.12 & 0.137 & 0.050 & 0.225 & 0.015 \\
\hline Denver (POST) & 488 & 2.08 & 0.109 & 0.041 & 0.263 & 0.015 \\
\hline Detroit (NEWS) & 317 & 2.63 & 0.130 & 0.036 & 0.317 & 0.006 \\
\hline Houston (CHRONICLE) & 607 & 2.18 & 0.164 & 0.047 & 0.372 & 0.011 \\
\hline Las Vegas (REVIEW-JOURNAL) & 167 & 2.20 & 0.087 & 0.018 & 0.282 & 0.010 \\
\hline Los Angeles (TIMES) & 1913 & 2.13 & 0.218 & 0.112 & 0.279 & 0.047 \\
\hline Minneapolis (STAR-TRIBUNE) & 445 & 2.08 & 0.218 & 0.036 & 0.305 & 0.012 \\
\hline New Orleans (TIMES-PICAYUNE) & 134 & 2.41 & 0.086 & 0.016 & 0.657 & 0.006 \\
\hline New York (TIMES) & 2808 & 2.28 & 0.211 & 0.152 & 0.300 & 0.154 \\
\hline Pittsburgh (POST-GAZETTE) & 318 & 2.28 & 0.151 & 0.031 & 0.365 & 0.038 \\
\hline Sacramento (BEE) & 500 & 2.20 & 0.128 & 0.077 & 0.011 & 0.002 \\
\hline San Antonio (EXPRESS NEWS) & 142 & 2.31 & 0.091 & 0.016 & 0.401 & 0.035 \\
\hline San Diego (UNION-TRIBUNE) & 517 & 2.14 & 0.161 & 0.047 & 0.500 & 0.029 \\
\hline San Francisco (CHRONICLE) & 4076 & 2.17 & 0.444 & 0.151 & 0.260 & 0.008 \\
\hline Seattle (POST-INTELLIGENCER) & 1019 & 2.11 & 0.301 & 0.060 & 0.461 & 0.013 \\
\hline St. Louis (POST-DISPATCH) & 241 & 2.06 & 0.143 & 0.021 & 0.628 & 0.008 \\
\hline St. Petersburg (TIMES) & 243 & 2.52 & 0.069 & 0.028 & 0.243 & 0.015 \\
\hline Washington D.C. (POST) & 983 & 2.42 & 0.188 & 0.079 & 0.513 & 0.029 \\
\hline USA TODAY & -- & -- & -- & -- & 0.023 & 0.041 \\
\hline WALL STREET J OURNAL & -- & -- & -- & -- & 0.438 & 0.318 \\
\hline
\end{tabular}

\begin{tabular}{|c|c|c|c|c|c|c|c|}
\hline & Mean & Standard Deviation & 1st Percentile & 10th Percentile & Median & 90th Percentile & 99th Percentile \\
\hline Market Capitalization (in millions) & 5660 & 10676 & 62 & 466 & 2513 & 12825 & 54479 \\
\hline SUE & 0.001 & 0.065 & -0.120 & -0.014 & 0.002 & 0.013 & 0.113 \\
\hline Stocks Held (per household) & 2.263 & 2.406 & 1.000 & 1.000 & 1.000 & 4.000 & 12.00 \\
\hline Stocks Traded (per month per household) & 1.75 & 1.78 & 1.00 & 1.00 & 1.00 & 3.00 & 9.00 \\
\hline Number of papers that cover EA & 0.879 & 1.534 & 0.000 & 0.000 & 0.000 & 3.000 & 7.00 \\
\hline Local Media Coverage (Dummy) & 0.028 & 0.166 & 0.000 & 0.000 & 0.000 & 0.000 & 1.000 \\
\hline
\end{tabular}




\section{Table 2: Media Effects and the Trading of Households}

Every firm earnings announcement in our sample corresponds to nineteen distinct observations representing trading in each of nineteen major U.S. cities which we call "trading areas." The dependent variable is the natural logarithm of one plus the dollar trading volume in each trading area for the firm that makes the earnings announcement where local trading volume is available between J anuary 1991 and November 1996 and is taken from the discount brokerage database in Barber and Odean (2000). Trading volume is considered on day 0, 1 or 2 following the earnings announcement date as identified by COMPUSTAT and I/B/E/S. Local Media Coverage takes the value one if the local newspaper (i.e. the newspaper that corresponds to the trading area) wrote a story about the firm on day $+0,+1$ or +2 following the earnings announcement. Controls include the natural logarithm of market capitalization (size), dummy variables for varying quintiles of earnings surprise (SUE quintiles), dummy variables for coverage in each of our local and national newspapers, dummy variables for each of the nineteen trading areas and date fixed effects. Robust standard errors clustered by firm are in parentheses. *, **, and *** represent significance at the $10 \%, 5 \%$ and $1 \%$ levels, respectively. 


\begin{tabular}{|c|c|c|c|c|c|}
\hline & Dependent Vari & g Dollar & Volume & & \\
\hline Local Media Coverage & $\begin{array}{l}0.746^{* * * *} \\
(0.0830)\end{array}$ & $\begin{array}{l}0.658^{* * * *} \\
(0.0739)\end{array}$ & $\begin{array}{l}0.648^{* * *} \\
(0.0739)\end{array}$ & $\begin{array}{l}0.370 * * * \\
(0.0458)\end{array}$ & $\begin{array}{l}0.477 * * * * \\
(0.0593)\end{array}$ \\
\hline Firm Size & & $\begin{array}{r}0.0700^{* * *} \\
(0.0103)\end{array}$ & $\begin{array}{r}0.0761^{* * * *} \\
(0.0108)\end{array}$ & $\begin{array}{r}0.0506^{* * *} \\
(0.0100)\end{array}$ & $\begin{array}{r}0.0577 * * * * \\
(0.0113)\end{array}$ \\
\hline SUE Quintile $=$ Lowest & & & $\begin{array}{r}0.0758^{* * *} \\
(0.0158)\end{array}$ & $\begin{array}{r}0.0381^{* * * *} \\
(0.0153)\end{array}$ & $\begin{array}{r}0.0526^{* * *} \\
(0.0171)\end{array}$ \\
\hline SUE Quintile = 2 & & & $\begin{array}{r}0.0128 \\
(0.00950)\end{array}$ & $\begin{array}{r}0.00223 \\
(0.0084)\end{array}$ & $\begin{array}{r}0.00988 \\
(0.00921)\end{array}$ \\
\hline SUE Quintile $=4$ & & & $\begin{array}{r}0.0308^{* *} \\
(0.0119)\end{array}$ & $\begin{array}{l}0.00688 \\
(0.0093)\end{array}$ & $\begin{array}{c}0.0235 * * \\
(0.0107)\end{array}$ \\
\hline SUE Quintile $=$ Highest & & & $\begin{array}{r}0.0845^{* * * *} \\
(0.0185)\end{array}$ & $\begin{array}{r}0.0502^{* * * *} \\
(0.0177)\end{array}$ & $\begin{array}{r}0.0661^{* * *} \\
(0.0197)\end{array}$ \\
\hline Coverage in Boston Globe & & & & $\begin{array}{r}-0.235^{* *} \\
(0.101)\end{array}$ & $\begin{array}{r}0.0305 \\
(0.0426)\end{array}$ \\
\hline Coverage in Denver Post & & & & $\begin{array}{r}0.122 \\
(0.111)\end{array}$ & $\begin{array}{r}-0.00496 \\
(0.0501)\end{array}$ \\
\hline Coverage in Detroit News & & & & $\begin{array}{r}-0.102 \\
(0.0953)\end{array}$ & $\begin{array}{r}0.0814 \\
(0.0641)\end{array}$ \\
\hline Coverage in Houston Chronicle & & & & $\begin{array}{r}0.148 \\
(0.0990)\end{array}$ & $\begin{array}{r}0.0257 \\
(0.0431)\end{array}$ \\
\hline Coverage in Las Vegas Review-J ournal & & & & $\begin{array}{l}-0.122 \\
(0.111)\end{array}$ & $\begin{array}{r}-0.0671 \\
(0.0474)\end{array}$ \\
\hline Coverage in Los Angeles Times & & & & $\begin{array}{r}0.0416 \\
(0.0974)\end{array}$ & $\begin{array}{r}0.0618^{*} \\
(0.0356)\end{array}$ \\
\hline Coverage in New York Times & & & & $\begin{array}{r}-0.0618 \\
(0.0386)\end{array}$ & $\begin{array}{c}0.0341^{* *} \\
(0.0154)\end{array}$ \\
\hline Coverage in Pittsburgh Post-Gazette & & & & $\begin{array}{r}-0.00631 \\
(0.0860)\end{array}$ & $\begin{array}{c}0.0891 * \\
(0.0457)\end{array}$ \\
\hline Coverage in San Antonio Express News & & & & $\begin{array}{r}0.00900 \\
(0.120)\end{array}$ & $\begin{array}{c}-0.0298 \\
(0.0419)\end{array}$ \\
\hline Coverage in San Diego Union Tribune & & & & $\begin{array}{l}0.0384 \\
(0.159)\end{array}$ & $\begin{array}{r}0.0531 \\
(0.0612)\end{array}$ \\
\hline Coverage in San Francisco Chronicle & & & & $\begin{array}{r}-0.420^{* *} \\
(0.208)\end{array}$ & $\begin{array}{l}0.261^{* * * *} \\
(0.0759)\end{array}$ \\
\hline Coverage in Seattle Post-Intelligencer & & & & $\begin{array}{r}-0.107 \\
(0.376)\end{array}$ & $\begin{array}{r}0.168 \\
(0.187)\end{array}$ \\
\hline Coverage in St. Louis Post-Dispatch & & & & $\begin{array}{r}0.00945 \\
(0.0908)\end{array}$ & $\begin{array}{r}-0.0794 * * \\
(0.0381)\end{array}$ \\
\hline Coverage in St. Petersburg Times & & & & $\begin{array}{r}-2.118 * * * \\
(0.321)\end{array}$ & $\begin{array}{r}0.0519 \\
(0.140)\end{array}$ \\
\hline Coverage in Minneapolis Star-Tribune & & & & $\begin{array}{r}0.0453 \\
(0.0788)\end{array}$ & $\begin{array}{r}0.0580 \\
(0.0401)\end{array}$ \\
\hline Coverage in Atlanta J ournal-Constitution & & & & $\begin{array}{l}-0.188^{* *} \\
(0.0776)\end{array}$ & $\begin{array}{r}-0.0780 * * \\
(0.0353)\end{array}$ \\
\hline Coverage in Sacramento Bee & & & & $\begin{array}{r}-0.166 \\
(0.328)\end{array}$ & $\begin{array}{r}-0.152 \\
(0.259)\end{array}$ \\
\hline Coverage in Washington Post & & & & $\begin{array}{r}0.209 * * \\
(0.0813)\end{array}$ & $\begin{array}{l}0.0587 * * \\
(0.0288)\end{array}$ \\
\hline Coverage in New Orleans Times-Picayune & & & & $\begin{array}{r}-0.251^{* * * *} \\
(0.0850)\end{array}$ & $\begin{array}{r}-0.104^{* * *} \\
(0.0326)\end{array}$ \\
\hline Coverage in USA Today & & & & $\begin{array}{l}0.0742 \\
(0.120)\end{array}$ & $\begin{array}{l}0.173^{* * *} \\
(0.0382)\end{array}$ \\
\hline Coverage in Wall Street J ournal & & & & $\begin{array}{r}-0.0733^{* *} \\
(0.0347)\end{array}$ & $\begin{array}{c}-0.00561 \\
(0.0145)\end{array}$ \\
\hline Industry Fixed Effects & NO & NO & YES & YES & YES \\
\hline City Fixed Effects & NO & NO & NO & NO & YES \\
\hline Date Fixed Effects & YES & YES & YES & YES & YES \\
\hline Observations & 276982 & 276982 & 273999 & 265928 & 273999 \\
\hline Adjusted R² & 0.026 & 0.039 & 0.041 & 0.040 & 0.058 \\
\hline
\end{tabular}




\section{Table 3: Media Effects among Buys and Sells}

Every firm earnings announcement in our sample corresponds to nineteen distinct observations representing trading in each of nineteen major U.S. cities which we call "trading areas." The dependent variable is the natural logarithm of one plus the dollar trading volume in each trading area for the firm that makes the earnings announcement where local trading volume is available between J anuary 1991 and November 1996 and is taken from the discount brokerage database in Barber and Odean (2000). Trading volume is considered on day 0,1 or 2 following the earnings announcement date as identified by COMPUSTAT and I/B/E/ S. Local Covered takes the value one if the local newspaper (i.e. the newspaper that corresponds to the trading area) wrote a story about the firm on day 0,1 or 2 following the earnings announcement. The first five columns consider only buy volume while the second five columns only consider sell volume. Controls include the natural logarithm of market capitalization (size), dummy variables for varying quintiles of earnings surprise (SUE quintiles), dummy variables for coverage in each of our local and national newspapers, dummy variables for each of the nineteen trading areas and date fixed effects. Robust standard errors clustered by firm are in parentheses. *, **, and $* * *$ represent significance at the $10 \%, 5 \%$ and $1 \%$ levels, respectively.

\begin{tabular}{|c|c|c|c|c|c|c|c|c|c|c|}
\hline \multirow[b]{2}{*}{ Local Media Coverage } & \multicolumn{5}{|c|}{ "Dependent Variable: Log Dollar Trading Volume (Only Buys) } & \multicolumn{5}{|c|}{ Dependent Variable: Log Dollar Trading Volume (Only Sells) } \\
\hline & $\begin{array}{l}0.462^{* * *} \\
(0.0588)\end{array}$ & $\begin{array}{c}0.408^{* * *} \\
(0.0524)\end{array}$ & $\begin{array}{c}0.402^{* * *} \\
(0.0521)\end{array}$ & $\begin{array}{l}0.339 * * * \\
(0.0428)\end{array}$ & $\begin{array}{l}0.290^{\text {**** }} \\
(0.0406)\end{array}$ & $\begin{array}{l}0.381^{* * *} \\
(0.0464)\end{array}$ & $\begin{array}{c}0.341^{* * *} \\
(0.0426)\end{array}$ & $\begin{array}{l}0.335^{* * *} \\
(0.0430)\end{array}$ & $\begin{array}{c}0.307^{* * * *} \\
(0.0391)\end{array}$ & $\begin{array}{c}0.260 * * * \\
(0.0374)\end{array}$ \\
\hline Firm Size & & $\begin{array}{l}0.0446^{* * *} \\
(0.00684)\end{array}$ & $\begin{array}{r}0.0480^{* * *} \\
(0.00714)\end{array}$ & $\begin{array}{c}0.0341^{* * *} \\
(0.00686)\end{array}$ & $\begin{array}{c}0.0341^{* * *} \\
(0.00686)\end{array}$ & & $\begin{array}{l}0.0312^{* * *} \\
(0.00515)\end{array}$ & $\begin{array}{l}0.0342^{* * *} \\
(0.00540)\end{array}$ & $\begin{array}{c}0.0268^{* * *} \\
(0.00581)\end{array}$ & $\begin{array}{c}0.0268^{* * *} \\
(0.00581)\end{array}$ \\
\hline SUE Quintile = Lowest & & & $\begin{array}{r}0.0388^{* * *} \\
(0.0104)\end{array}$ & $\begin{array}{c}0.0191 * \\
(0.0107)\end{array}$ & $\begin{array}{c}0.0191 * \\
(0.0107)\end{array}$ & & & $\begin{array}{l}0.0438^{* * *} \\
(0.00864)\end{array}$ & $\begin{array}{c}0.0321^{* * *} \\
(0.00932)\end{array}$ & $\begin{array}{c}0.0321^{* * *} \\
(0.00932)\end{array}$ \\
\hline SUE Quintile $=2$ & & & $\begin{array}{c}0.000173 \\
(0.00716)\end{array}$ & $\begin{array}{r}-0.00407 \\
(0.00672)\end{array}$ & $\begin{array}{r}-0.00407 \\
(0.00672)\end{array}$ & & & $\begin{array}{l}0.0150 * * * \\
(0.00564)\end{array}$ & $\begin{array}{r}0.0130 * * \\
(0.00561)\end{array}$ & $\begin{array}{r}0.0130 * * \\
(0.00561)\end{array}$ \\
\hline SUE Quintile $=4$ & & & $\begin{array}{r}0.00898 \\
(0.00885)\end{array}$ & $\begin{array}{r}0.00340 \\
(0.00786)\end{array}$ & $\begin{array}{r}0.00340 \\
(0.00786)\end{array}$ & & & $\begin{array}{c}0.0261^{* * *} \\
(0.00690)\end{array}$ & $\begin{array}{c}0.0211^{* * *} \\
(0.00623)\end{array}$ & $\begin{array}{c}0.0211^{* * *} \\
(0.00623)\end{array}$ \\
\hline SUE Quintile $=$ Highest & & & $\begin{array}{r}0.0457^{* * *} \\
(0.0120)\end{array}$ & $\begin{array}{r}0.0309 * * * \\
(0.0116)\end{array}$ & $\begin{array}{r}0.0309^{* * *} \\
(0.0116)\end{array}$ & & & $\begin{array}{r}0.0469^{* * *} \\
(0.0113)\end{array}$ & $\begin{array}{r}0.0386^{* * *} \\
(0.0123)\end{array}$ & $\begin{array}{r}0.0386^{* * *} \\
(0.0123)\end{array}$ \\
\hline Industry Fixed Effects & NO & NO & YES & YES & YES & NO & NO & YES & YES & YES \\
\hline Paper Fixed Effects & NO & NO & $\mathrm{NO}$ & YES & YES & NO & NO & NO & YES & YES \\
\hline City Fixed Effects & $\mathrm{NO}$ & NO & $\mathrm{NO}$ & NO & YES & $\mathrm{NO}$ & NO & NO & NO & YES \\
\hline Date Fixed Effects & YES & YES & YES & YES & YES & YES & YES & YES & YES & YES \\
\hline Observations & 276982 & 276982 & 273999 & 273999 & 273999 & 276982 & 276982 & 273999 & 273999 & 273999 \\
\hline Adjusted R2 & 0.022 & 0.031 & 0.032 & 0.041 & 0.048 & 0.015 & 0.021 & 0.022 & 0.026 & 0.034 \\
\hline
\end{tabular}




\section{Table 4: Media Effects and Determinants of Local Trading}

Every firm earnings announcement in our sample corresponds to nineteen distinct observations representing trading in each of nineteen major U.S. cities which we call "trading areas." The dependent variable is the natural logarithm of one plus the dollar trading volume in each trading area for the firm that makes the earnings announcement where local trading volume is taken from the discount brokerage database in Barber and Odean (2000). Trading volume is considered on day 0, 1 or 2 following the earnings announcement date as identified by COMPUSTAT and I/B/E/ S. Local Covered takes the value one if the local newspaper (i.e. the newspaper that corresponds to the trading area) wrote a story about the firm on day 0, 1 or 2 following the earnings announcement. Local Firm Dummy takes the value one if the firm is local to the trading market. Fraction of Accounts Holding is the fraction of accounts in the trading area holding the stock as of the first day of the month. Fraction of Accounts Trading is the fraction of accounts in the trading area that traded the stock in the prior month. Controls include the natural logarithm of market capitalization (size), dummy variables for varying quintiles of earnings surprise (SUE quintiles), dummy variables for coverage in each of our local and national newspapers, dummy variables for each of the nineteen trading areas and date fixed effects. Robust standard errors clustered by firm are in parentheses. $*, * *$, and $* * *$ represent significance at the $10 \%, 5 \%$ and $1 \%$ levels, respectively.

\begin{tabular}{|c|c|c|c|c|c|}
\hline \multirow{3}{*}{ Local Media Coverage } & \multicolumn{4}{|c|}{ " Dependent Variable: Log Dollar Trading Volume } & \multirow{3}{*}{$\begin{array}{l} \\
0.281^{* * *} \\
(0.0510)\end{array}$} \\
\hline & ONLY NON-LOCAL FIRMS & & & & \\
\hline & $\begin{array}{r}0.283^{* * *} \\
(0.0412)\end{array}$ & $\begin{array}{l}0.327 * * * \\
(0.0527)\end{array}$ & $\begin{array}{l}0.382^{* * *} \\
(0.0570)\end{array}$ & $\begin{array}{l}0.454^{* * *} \\
(0.0569)\end{array}$ & \\
\hline Firm Size & $\begin{array}{l}0.0508^{* * *} \\
(0.00999)\end{array}$ & $\begin{array}{r}0.0565^{* * *} \\
(0.0112)\end{array}$ & $\begin{array}{l}0.0234 * * * \\
(0.00532)\end{array}$ & $\begin{array}{l}0.0476 * * * \\
(0.00922)\end{array}$ & $\begin{array}{l}0.0230 * * * \\
(0.00495)\end{array}$ \\
\hline SUE Quintile $=$ Lowest & $\begin{array}{r}0.0384 * * \\
(0.0154)\end{array}$ & $\begin{array}{r}0.0479 * * * \\
(0.0170)\end{array}$ & $\begin{array}{r}0.0283^{* * *} \\
(0.0101)\end{array}$ & $\begin{array}{r}0.0401^{* * *} \\
(0.0141)\end{array}$ & $\begin{array}{l}0.0255^{* * *} \\
(0.00940)\end{array}$ \\
\hline SUE Quintile $=2$ & $\begin{array}{r}0.00275 \\
(0.00838)\end{array}$ & $\begin{array}{r}0.00740 \\
(0.00907)\end{array}$ & $\begin{array}{r}0.00113 \\
(0.00789)\end{array}$ & $\begin{array}{r}0.00532 \\
(0.00853)\end{array}$ & $\begin{array}{l}0.000547 \\
(0.00772)\end{array}$ \\
\hline SUE Quintile $=4$ & $\begin{array}{r}0.00732 \\
(0.00934)\end{array}$ & $\begin{array}{l}0.0212^{* *} \\
(0.0105)\end{array}$ & $\begin{array}{l}0.0231 * * * \\
(0.00873)\end{array}$ & $\begin{array}{r}0.0197 * * \\
(0.00955)\end{array}$ & $\begin{array}{r}0.0212 * * \\
(0.00839)\end{array}$ \\
\hline SUE Quintile $=$ Highest & $\begin{array}{r}0.0509 * * * \\
(0.0178)\end{array}$ & $\begin{array}{r}0.0622^{* * *} \\
(0.0196)\end{array}$ & $\begin{array}{r}0.0474 * * * \\
(0.0124)\end{array}$ & $\begin{array}{r}0.0568 * * * \\
(0.0173)\end{array}$ & $\begin{array}{r}0.0449 * * * \\
(0.0119)\end{array}$ \\
\hline Local Firm Dummy & & $\begin{array}{l}0.492^{* * *} \\
(0.0598)\end{array}$ & & & $\begin{array}{l}0.336 * * * \\
(0.0518)\end{array}$ \\
\hline Fraction of Accounts Holding & & & $\begin{array}{r}28.34 * * * \\
(3.030)\end{array}$ & & $\begin{array}{r}23.16^{* * *} \\
(2.764)\end{array}$ \\
\hline Fraction of Accounts Trading & & & & $\begin{array}{r}69.78^{* * *} \\
(6.974)\end{array}$ & $\begin{array}{r}50.79 * * * \\
(4.976)\end{array}$ \\
\hline Industry Fixed Effects & YES & YES & YES & YES & YES \\
\hline Paper Fixed Effects & YES & YES & YES & YES & YES \\
\hline City Fixed Effects & YES & YES & YES & YES & YES \\
\hline Date Fixed Effects & YES & YES & YES & YES & YES \\
\hline Observations & 265928 & 273999 & 273999 & 273999 & 273999 \\
\hline Adjusted R2 & 0.049 & 0.068 & 0.081 & 0.073 & 0.089 \\
\hline
\end{tabular}




\section{Table 5: Media Effects, Newspaper Delivery and Local Weather}

Every firm earnings announcement in our sample corresponds to nineteen distinct observations representing trading in each of nineteen major U.S. cities which we call "trading areas." The dependent variable is the natural logarithm of one plus the dollar trading volume in each trading area for the firm that makes the earnings announcement and is taken from the discount brokerage database in Barber and Odean (2000). Local Covered takes the value one if the local newspaper (i.e. the newspaper that corresponds to the trading area) wrote a story about the firm on day 0,1 or 2 following the earnings announcement date as identified by COMPUSTAT and I/B/E/S. Weather data are taken from the National Climatic Data Center at ftp:/ /ftp.ncdc.noaa.gov/pub/ data/gsod. For each trading area, we use weather from the station closest to the local newspaper's zip code. Local Hail is a dummy variable that takes the value one if there was hail during the two days after the earnings announcement. Local Snow is a dummy variable that takes the value one if there was at least 8 inches of new snowfall during the two days after the earnings announcement. Extreme Weather is a dummy variable takes the value of one if either Local Hail or Local Snow take the value of one. Controls include the natural logarithm of market capitalization (size), dummy variables for varying quintiles of earnings surprise (SUE quintiles), dummy variables for coverage in each of our local and national newspapers, dummy variables for each of the nineteen trading areas and date fixed effects. Robust standard errors clustered by firm are in parentheses. $*, * *$, and $* * *$ represent significance at the $10 \%, 5 \%$ and $1 \%$ levels, respectively.

\begin{tabular}{|c|c|c|c|}
\hline \multirow[b]{2}{*}{ Local Media Coverage } & \multicolumn{3}{|c|}{ Dependent Variable: Log Dollar Trading Volume } \\
\hline & $\begin{array}{l}0.478^{* * * *} \\
(0.0594)\end{array}$ & $\begin{array}{l}0.478 * * * \\
(0.0593)\end{array}$ & $\begin{array}{l}0.479 * * * \\
(0.0593)\end{array}$ \\
\hline Firm Size & $\begin{array}{r}0.0459 * * * \\
(0.0104)\end{array}$ & $\begin{array}{r}0.0565 * * * \\
(0.0113)\end{array}$ & $\begin{array}{r}0.0565^{* * *} \\
(0.0113)\end{array}$ \\
\hline SUE Quintile = Lowest & $\begin{array}{r}0.0381 * * \\
(0.0157)\end{array}$ & $\begin{array}{r}0.0484^{* * *} * \\
(0.0170)\end{array}$ & $\begin{array}{r}0.0484^{* * *} \\
(0.0170)\end{array}$ \\
\hline SUE Quintile $=2$ & $\begin{array}{l}-0.00504 \\
(0.00913)\end{array}$ & $\begin{array}{r}0.00754 \\
(0.00908)\end{array}$ & $\begin{array}{r}0.00752 \\
(0.00908)\end{array}$ \\
\hline SUE Quintile $=4$ & $\begin{array}{c}0.0193^{*} \\
(0.0114)\end{array}$ & $\begin{array}{c}0.0216 * * \\
(0.0105)\end{array}$ & $\begin{array}{c}0.0216^{* *} \\
(0.0105)\end{array}$ \\
\hline SUE Quintile $=$ Highest & $\begin{array}{r}0.0522^{* * *} \\
(0.0186)\end{array}$ & $\begin{array}{r}0.0633 * * * \\
(0.0197)\end{array}$ & $\begin{array}{r}0.0632^{* * *} \\
(0.0197)\end{array}$ \\
\hline Local Hail & $\begin{array}{r}0.0998 \\
(0.0745)\end{array}$ & & \\
\hline Local Hail * Local Media Coverage & $\begin{array}{r}-0.922^{* * *} \\
(0.129)\end{array}$ & & \\
\hline Local Snow & & $\begin{array}{r}0.0486 \\
(0.0352)\end{array}$ & \\
\hline Local Snow* Local Media Coverage & & $\begin{array}{r}-0.774 * * * \\
(0.135)\end{array}$ & \\
\hline Local Extreme Weather & & & $\begin{array}{r}0.0641^{*} \\
(0.0344)\end{array}$ \\
\hline Local Extreme Weather* Local Media Coverage & & & $\begin{array}{r}-0.790^{* * *} \\
(0.105)\end{array}$ \\
\hline Industry Fixed Effects & YES & YES & YES \\
\hline Paper Fixed Effects & YES & YES & YES \\
\hline City Fixed Effects & YES & YES & YES \\
\hline Date Fixed Effects & YES & YES & YES \\
\hline Observations & 273999 & 273999 & 273999 \\
\hline Adjusted R2 & 0.051 & 0.063 & 0.063 \\
\hline
\end{tabular}




\section{Table 6: Media Effects and Alternative Definitions of Household Trading}

Every firm earnings announcement in our sample corresponds to nineteen distinct observations representing trading in each of nineteen major U.S. cities which we call "trading areas." The dependent variable is some measure of trading volume in each trading area for the firm that makes the earnings announcement where local trading volume is available between January 1991 and November 1996 and is taken from the discount brokerage database in Barber and Odean (2000). Trading volume is considered on day 0, 1 or 2 following the earnings announcement date as identified by COMPUSTAT and I/B/E/S. Local Covered takes the value one if the local newspaper (i.e. the newspaper that corresponds to the trading area) wrote a story about the firm on day 0,1 or 2 following the earnings announcement. In the first three columns, the dependent variable is a dummy variable that takes the value one if there was any trading in the firm making the earnings announcement. In the second three columns, the dependent variable is the natural logarithm of one plus the number of accounts that traded in the firm making the earnings announcement. Controls include the natural logarithm of market capitalization (size), dummy variables for varying quintiles of earnings surprise (SUE quintiles), dummy variables for coverage in each of our local and national newspapers, dummy variables for each of the nineteen trading areas and date fixed effects. Robust standard errors clustered by firm are in parentheses. *, **, and *** represent significance at the $10 \%, 5 \%$ and $1 \%$ levels, respectively.

\begin{tabular}{|c|c|c|c|c|c|c|}
\hline & \multicolumn{3}{|c|}{ Dependent Variable: Log Number of Accounts Traded } & \multicolumn{3}{|c|}{ Dependent Variable: Local Trading Dummy } \\
\hline & ALL TRADES & BUYS ONLY & SELLS ONLY & ALL TRADES & BUYS ONLY & SELLS ONLY \\
\hline Local Media Coverage & $\begin{array}{l}0.0467^{* * *} \\
(0.00673)\end{array}$ & $\begin{array}{l}0.0272^{* * *} \\
(0.00427)\end{array}$ & $\begin{array}{l}0.0230 * * * \\
(0.00369)\end{array}$ & $\begin{array}{c}0.0501^{* * *} \\
(0.00591)\end{array}$ & $\begin{array}{l}0.0311^{* * *} \\
(0.00421)\end{array}$ & $\begin{array}{l}0.0277 * * * \\
(0.00389)\end{array}$ \\
\hline Firm Size & $\begin{array}{r}0.00487 * * * \\
(0.00103)\end{array}$ & $\begin{array}{l}0.00281^{* * *} \\
(0.000576)\end{array}$ & $\begin{array}{l}0.00224^{* * *} \\
(0.000531)\end{array}$ & $\begin{array}{r}0.00604^{* * * *} \\
(0.00118)\end{array}$ & $\begin{array}{l}0.00368 * * * \\
(0.000729)\end{array}$ & $\begin{array}{l}0.00286^{* * *} \\
(0.000613)\end{array}$ \\
\hline SUE Quintile = Lowest & $\begin{array}{r}0.00422^{* * * *} \\
(0.00156)\end{array}$ & $\begin{array}{r}0.00153^{*} \\
(0.000926)\end{array}$ & $\begin{array}{l}0.00279 * * * \\
(0.000832)\end{array}$ & $\begin{array}{r}0.00556 * * * \\
(0.00182)\end{array}$ & $\begin{array}{l}0.00226^{*} \\
(0.00116)\end{array}$ & $\begin{array}{r}0.00363^{* * *} \\
(0.00101)\end{array}$ \\
\hline SUE Quintile $=2$ & $\begin{array}{r}0.000766 \\
(0.000800)\end{array}$ & $\begin{array}{r}-0.000240 \\
(0.000588)\end{array}$ & $\begin{array}{r}0.00107^{* *} \\
(0.000457)\end{array}$ & $\begin{array}{r}0.000937 \\
(0.000993)\end{array}$ & $\begin{array}{r}-0.000387 \\
(0.000738)\end{array}$ & $\begin{array}{r}0.00148^{* *} \\
(0.000617)\end{array}$ \\
\hline SUE Quintile $=4$ & $\begin{array}{r}0.00203^{* *} \\
(0.000965)\end{array}$ & $\begin{array}{r}0.000382 \\
(0.000735)\end{array}$ & $\begin{array}{l}0.00179 * * * \\
(0.000512)\end{array}$ & $\begin{array}{r}0.00220 * * \\
(0.00110)\end{array}$ & $\begin{array}{r}0.000269 \\
(0.000833)\end{array}$ & $\begin{array}{l}0.00224^{* * *} \\
(0.000660)\end{array}$ \\
\hline SUE Quintile = Highest & $\begin{array}{r}0.00544^{* * *} \\
(0.00183)\end{array}$ & $\begin{array}{l}0.00241^{* *} \\
(0.00102)\end{array}$ & $\begin{array}{r}0.00327 * * * \\
(0.00111)\end{array}$ & $\begin{array}{r}0.00669 * * * \\
(0.00205)\end{array}$ & $\begin{array}{r}0.00327 * * * \\
(0.00123)\end{array}$ & $\begin{array}{r}0.00411 * * * \\
(0.00130)\end{array}$ \\
\hline Industry Fixed Effects & YES & YES & YES & YES & YES & YES \\
\hline Paper Fixed Effects & YES & YES & YES & YES & YES & YES \\
\hline City Fixed Effects & YES & YES & YES & YES & YES & YES \\
\hline Date Fixed Effects & YES & YES & YES & YES & YES & YES \\
\hline Observations & 273999 & 273999 & 273999 & 273999 & 273999 & 273999 \\
\hline Adjusted R2 & 0.070 & 0.054 & 0.035 & 0.060 & 0.047 & 0.033 \\
\hline
\end{tabular}




\section{Table 7: Media Effects and Robustness}

Every firm earnings announcement in our sample corresponds to nineteen distinct observations representing trading in each of nineteen major U.S. cities which we call "trading areas." The dependent variable is the natural logarithm of one plus the dollar trading volume in each trading area for the firm that makes the earnings announcement where local trading volume is available between J anuary 1991 and November 1996 and is taken from the discount brokerage database in Barber and Odean (2000). Controls include Firm-Date, Firm-City and City-Date fixed effects. Robust standard errors clustered by firm are in parentheses. *, **, and *** represent significance at the $10 \%, 5 \%$ and $1 \%$ levels, respectively.

Dependent Variable: Log Dollar Trading Volume

\begin{tabular}{lrrrr}
\hline Local Coverage & $0.477^{* * *}$ & $0.0755^{* *}$ & $0.473^{* * *}$ & $0.0796^{* * *}$ \\
& $(0.0587)$ & $(0.0295)$ & $(0.0535)$ & $(0.0281)$ \\
& & & & \\
Firm-Date Fixed Effects & YES & NO & NO & YES \\
Firm-City Fixed Effects & NO & YES & NO & YES \\
City-Date Fixed Effects & NO & NO & YES & YES \\
Observations & 273999 & 273999 & 273999 & 273999 \\
Adjusted R2 & 0.093 & 0.164 & 0.106 & 0.289 \\
\hline \hline
\end{tabular}




\section{Table 8: Media Effects, the Timing of Stories and Falsification}

Every firm earnings announcement in our sample corresponds to nineteen distinct observations representing trading in each of nineteen major U.S. cities which we call "trading areas." The dependent variable is the natural logarithm of one plus the dollar trading volume in each trading area for the firm that makes the earnings announcement where local trading volume is available between J anuary 1991 and November 1996 and is taken from the discount brokerage database in Barber and Odean (2000). In column $1(2,3)$ only trading volume on day $0(1,2)$ following the earnings announcement is considered. Local Coverage on Day $0(1,2)$ takes the value 1 if there was a news article in the local newspaper on day 0 $(1,2)$. Local Coverage on Non-Matched Day takes the value 1 if there was a news article on a different day than the trading day ( 1 day after or 2 days after). Controls include Firm-Date, Firm-City and City-Date fixed effects. Robust standard errors clustered by firm are in parentheses. *, **, and *** represent significance at the $10 \%, 5 \%$ and $1 \%$ levels, respectively.

Dependent Variable: Log Dollar Trading Volume

\begin{tabular}{lrrr} 
& On Day 0 & On Day 1 & On Day 2 \\
\hline Local Coverage on Day 0 & $0.0915 * *$ & -0.00914 \\
& $(0.0355)$ & $(0.0282)$ & $(0.0240)$ \\
& & & 0.0154 \\
Local Coverage on Day 1 & 0.0112 & $0.0688^{* *}$ & $(0.0193)$ \\
& $(0.0316)$ & $(0.0287)$ & 0.0643 \\
& & & $(0.0408)$ \\
Local Coverage on Day 2 & 0.0161 & 0.00941 & $(0.0551)$ \\
& $(0.0395)$ & & YES \\
Firm-Date Fixed Effects & & YES & YES \\
Firm-City Fixed Effects & YES & YES & YES \\
City-Date Fixed Effects & YES & YES & 273999 \\
Observations & 273999 & 0.264 & 0.222 \\
Adjusted R2 & 0.269 & & YES \\
\hline \hline
\end{tabular}

